\title{
Når isen forsvinder
}

\section{Nikolaj Petersen}

\section{Signalement af Danmarks og Rigsfællesskabets reaktion på nye muligheder og problemer}

Martin Breum: Når isen forsvinder. Danmark som stormagt i Arktis, olien i Grønland og kampen om Nordpolen. Gyldendal, København, 2011.

Tv-journalisten Martin Breum har skrevet, hvad han selv betegner som en "en hurtig, journalistisk sejlads gennem Danmarks arktiske engagement" (s. 245). Det er slet ingen ueffen karakteristik af bogen, der giver et bredt og læseværdigt signalement af Danmarks og Rigsfællesskabets reaktion på det kompleks af nye muligheder og problemer, som opvarmningen af Arktis, udsigten til et arktisk olieeventyr og den forestående deling af den ydre kontinentalsokkel i Det Arktiske Ocean tilsammen udgør.

Bogen er journalistisk i den forstand, at den i udpræget grad benytter sig af stilistiske virkemidler som dramatisk nutid, kronologiske spring, stemningsbilleder, dramatiseringer og skarpe vinklinger så som karakteriseringen af Danmark som en arktisk stormagt, det hele i en til tider vel pompøs sprogdragt. Dertil kommer et fravalg af 'akademiske' stiltræk som noter og henvisninger, begrebsdefinitioner ( $\mathrm{fx}$ hvad er en stormagt?), mv.

Bagest i bogen er der ganske vist et antal såkaldte 'noter', som imidlertid mest har karakter af faktabokse. Disse er til gengæld yderst nyttige, fordi man her finder de mest koncise oplysninger og enkeltanalyser serveret i et neutralt sprog. Men fraværet af egentlige kildehenvisninger yder ikke det omfattende materiale, som bogen tydeligvis bygger på, fuld retfærdighed.

\section{Sagens kerne}

Bogen indledes med en 'prolog', der over 12 sider refererer et seminar i det Kgl Danske Geografiske Selskab den 1. dec. 2009 om 'Nordpolen og den reducerede havis'. Seminaret, der åbnedes af HKH Kronprinsen, havde efter Breums tolkning et større perspektiv end som 


\section{LITTERATUR}

så, nemlig at demonstrere "Danmarks voksende magt og indflydelse i Arktis" og - "for første gang" præsentere den danske offentlighed "for et samlet indblik i de betydelige chancer og militære, diplomatiske og teknologiske udfordringer, nationen står over for" (s. 7).

Det er nok at tage munden for fuld: Seminarets fire emner, afsmeltningen, kontinentalsokkelprojektet, fremtidsperspektivet for arktisk sejlads samt arktisk sikkerhed, blev i henhold til mødeprogrammet afviklet på bare fem kvarter og synes ikke at have efterladt sig dybere spor i pressen. Denne havde faktisk fulgt den arktiske udvikling ret nøje, siden det russiske flag i august 2007 blev plantet på havbunden 4300 meter under Nordpolen.

Breums fokus på mødet i december 2009 synes snarest at være et stilistisk greb, der fra starten fører læseren in medias res, ind i kernen af bogens emnekreds.

\section{Markante udspil}

I bogens første kapitel tager Breum fat på Danmarks hidtil mest markante arktiske udspil, initiativet til Ilulissat-erklæringen af maj 2008, hvori de fem kyststater omkring Det Arktiske Ocean forpligtede sig og hinanden til at løse tvister på fredelig vis, samtidig med at de afviste behovet for et særligt regelsæt for regionen, der kunne give udenfor stående magter indflydelse. Initiativet var ifølge Breum en reaktion på den halvprivate russiske Nordpolsaktion i august 2007. Denne sammenhæng er evident, men der var også en sammenhæng med den aktivistiske klimapolitik forud for COP-15, blandt andet $i$ valget af Ilulissat som udenrigsministrenes mødested, samt et rivaliseringsmoment i forhold til Norge, der forberedte et lignende initiativ.

Breum har et skarpt øje for det kontroversielle i det danske initiativ, der syntes at afkoble Arktisk Råd og sætte en stopper for diskussionen af en evt. internationalisering af Det Arktiske Ocean. I et interview med initiativtageren, tidligere udenrigsminister Per Stig Møller medio 2010, medgiver denne da også, at initiativet var delvis motiveret af mistro til Arktisk Råd. Han erkender samtidig, at opfølgningen af initiativet er gået for langsomt, hvilket ikke er en overdrivelse. Er den arktiske 'stormagt' Danmark blevet ræd for sin egen skygge?

Set i det perspektiv synes Ilulissatinitiativet mest motiveret af ønsket om at forsvare Danmarks interesser i den forestående opdeling af den ydre kontinentalsokkel i det Arktiske Ocean mellem kyststaterne. Det er her Breum primært finder holdepunkter for sin karakteristik af Danmark som en aspirerende arktisk stormagt med et fast blik på selve Nordpolen. Kapitlet herom er koncentreret om det såkaldte kontinentalsokkel- projekt til indsamling af 
data, der kan overbevise FN om, at Danmark har ret til at udvide sin kontinentalsokkel i fem havområder omkring Færøerne og Grønland.

Breum følger projektet fra dets spæde begyndelse før årtusindskiftet til de senere år, hvor han ser voksende tegn på danske ambitioner på Nordpolen. Breum forklarer dette med 'Ekofisk- traumet', hvad meget taler for. Faktisk har dansk havretspolitik siden 1960'erne været ganske ekspansiv, jf. den årelange strid med Norge om grænsedragningen ved Jan Mayen eller striden med Canada om Hans $\varnothing$.

\section{Grønlandske interesser}

Varetagelsen af grønlandske og færøske interesser er et andet motiv, hvortil kommer "en grundlæggende trang til for enhver pris og ved enhver chance at udvide, forsvare, fasttømre Rigets territorium" som et tredje og måske afgørende motiv (s. 97).

Breum har sandsynligvis også ret på dette punkt. I det hele taget er han god til at afdække de mytiske og irrationelle aspekter af den arktiske politik. Til gengæld ligger han engang imellem selv under for dem, som når han taler om "den særlige mystik og tiltrækningskraft, der strømmer ud fra Nordpolen" (s. 73), eller når han registrerer, at sokkelprojektets leder Christian Marcussen er født ind i det tyske mindretal "med den særlige forståelse for Rigets grænser, som det giver" (s. 81).

Udsigterne til en grønlandsk olieog gasproduktion følges dernæst i et velorienteret kapitel, der fokuserer skarpt på det nuværende grønlandske selvstyres vilje til at modernisere den grønlandske økonomi og dermed nedprioritere den vægt på bæredygtig udvikling og miljøbeskyttelse, som regeringspartiet IA tidligere stod for. Kapitlet giver et fascinerende indblik i den grønlandske debat om de nye muligheder og risici og en god baggrund for forståelsen af den nye moderniseringspolitik og dens implikationer for Rigsfællesskabet. Efter indførelsen af det grønlandske selvstyre i 2009 er oliesektoren uden for rigsmyndighedernes kontrol, hvilket - med den nuværende raske grønlandske koncessionspolitik - kan skabe intrikate problemer for dansk udenrigspolitik.

I første instans vil et olieeventyr skabe, ikke en dansk, men en grønlandsk 'stormagt' i Arktis.

\section{Sikkerhedspolitiske implikationer}

I bogens sidste halvdel diskuterer Breum de sikkerhedspolitiske implikationer af udviklingen i Arktis. Han gør det i regi af et togt op langs $\emptyset_{\text {st- }}$ grønlands kyst med det nye inspektionsskib Ejnar Mikkelsen, som ikke er indlysende relevant i sammenhængen. Kapitlet starter med et malende, men reelt uvedkommende stemningsbillede af afsejlingen fra 


\section{LITTERATUR}

Reykjavik inklusive de medfølgende måger, der dog meldes forsvundet, da skibet når op under Grønland (!). Kapitlet er i øvrigt mest bundet op omkring en række udtalelser og analyser for og imod udsigterne til konflikter og oprustning i Arktis, der ikke giver nogen fast konklusion. Dette gælder også den danske sikkerhedspolitik for Arktis, der sandt at sige heller ikke er let at gennemskue. Kapitlet slutter dog med at nedtone risikoen for alvorlig konflikter i Arktis, samtidig med at interessen for området er stigende.

Slutreplikken lyder tro mod den malende sproglige stil: "Mens krigene i Irak og Afghanistan er under afvikling rettes kikkerterne mod nord, samme vej som Ejnar Mikkelsen sejler" (s. 188).

Et andet problem, der tages op, er konsekvenserne af den voksende arktiske skibsfart i kølvandet af det danske skib Peter Faber, der i 2008 som det første skib passerede Nordøstpassagen uden isbryderassistance. Et andet træk er krydstogtskibenes forkærlighed for de dårligt opmålte grønlandske farvande. Problemet her er et manglende søredningsberedskab i Arktis, hvis et stort krydstogtskib skulle forlise.
Et sidste træk ved bogen, som skal nævnes, er hyppige referencer tilbage til pionererne, Knud Rasmussen først og fremmest, hvis motto "Den der raster, ruster" forfatteren gør til sin eget i sin karakteristik af ånden i dansk og grønlandsk politik som overraskende aktivistisk.

I bogens epilog slår denne tolkning stærkt igennem, når det hedder, at 100 år efter Knud Rasmussen "er danskerne stadig besjælet af en intens virkelyst i det arktiske, helt i tråd med den energi, der strømmede fra pionererne og med arven fra vikingerne. Den der raster, ruster. Trangen til at udstrække nationens grænser til det yderste, forske i det ukendte, udvide Riget og indlemme nyt territorium driver stadig Danmarks statsministre, diplomater, embedsmænd og forskere, og som forgængerne opererer de konsekvent med sigte på nationens ve og vel." (s. 243)

Ikke alle vil gå så vidt, hvad der dog ikke mindsker bogens fortjeneste som en informeret indføring i den rigt facetterede arktiske problematik.

Nikolaj Petersen, professor emeritus. 